named, has already had an effect. Pressure from the local union branch at the University of Aston in Birmingham persuaded the university to postpone compulsory redundancies at least until the next academic year. Local pressure also persuaded the University of Keele to withdraw its notification of 300 impending redundancies to the Department of Employment. Other universities have also decided to delay job losses in an attempt to avoid being the first to be dragged through the courts. A handful are also apparently planning not to balance their books for several years. Their policy of living on borrowed money perhaps for three or four years is favoured by the AUT.

Judy Redfearn

\section{Science research council}

\section{Paying a price}

The capacity of the Science and Engineering Research Council to make research grants to British academics is likely to be impaired, in the year immediately ahead, because of the overspending by the council's Science Board, in the financial year that ended on 31 March. One of the ironies of this situation, described in the council's annual report for 1980-81, published last week, is that the chairman of the offending board, Professor John Kingman, has now succeeded Sir Geoffrey Allen as chairman of the council.

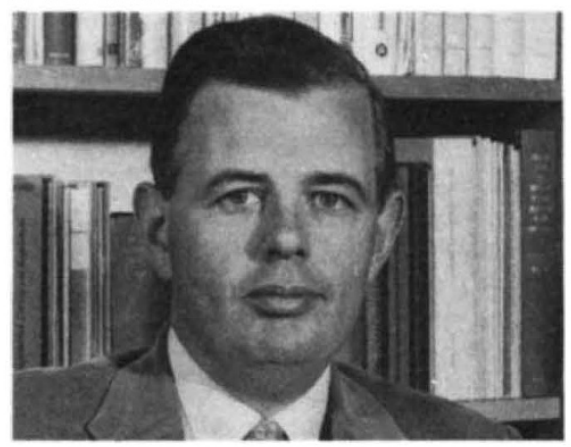

Kingman - poacher to gamekeeper?

According to the report, the council's allocation of funds to the science board will be reduced in the current year, while the board must repay to its master the outstanding amount of its over-spending.

The over-spending occurred, according to Professor Kingman, when the council decided to adopt a more bullish attitude to its spending to avoid falling into the trap of having money that it had not spent taken away by the government. In the event, it over-stepped the mark and received a sharp rap over the knuckles from the House of Commons Public Accounts Committee and a warning not to over-spend again.

Professor Kingman is confident that the council can do better this year. He expects spending to be within 0.15 per cent of the budget, the margin allowed by the Treasury, which he nevertheless complains is too narrow and would never be expected in industry.

Although the science board over-spent by only a small fraction of its annual budget ( $£ 64.4$ million in $1980-81$ ), the effect on its activities has been marked. During 1980-81, the announcement of some research grants to universities had to be delayed for lack of funds. The repayments this year and next will also not help the board meet its future commitments, about one-third of which are to research and teaching in universities.

According to the annual report, support for university research, a third of which is channelled through the science board, had to be cut somewhat during 1980-81. Matters this year are complicated by the cut in university income which is increasing pressure on the council's research grants.

But the report, for which Sir Geoffrey Allen is responsible, says that spending on research grants should soon be restored at least to the level of recent years. Nevertheless, it is unlikely that the council will be able to support all grant applications given its highest merit grading of alpha.

The council, in 1980-82, spent $£ 56.5$ million on research grants out of its total budget of $£ 207.8$ million. A few more grants were awarded than in the previous year but the increase was due almost entirely to an unusually large number of requests for continuing support in some areas. A total of 1,983 research grants, valued at $£ 74.5$ million, were recommended in 1980-81 compared with 2,412 awarded in 1979-80.

Judy Redfearn

\section{New man in}

Within a week of the resignation of the president and director-general of the French research agency, the Centre National de la Recherche Scientifique (CNRS) (Nature 5 November, p.3), a new director-general has been appointed: the long-time socialist party member M. Jean-Jacques Payan, a 46-year-old mathematician, and president of the University of Grenoble I.

The presidency of CNRS remains unfilled, although constitutionally the president has to help select the directorgeneral. However, the director-general bears the main management load, and so the filling of this post was considered the more urgent.

M. Payan's first task will be to reestablish confidence in the CNRS management, to represent CNRS in the national colloquium on science and technology (which takes place in January) and to consider the reorganization of CNRS - particularly taking into account the strongly expressed wish of the engineers, technicians and administrators of the many CNRS laboratories to play a more significant role in policy-making.

Robert Walgate
German energy policy

\section{The future unclear}

Count Otto Lambsdorff, the West German economics minister, was balanced on a precarious political tight-rope last week, when he announced the governing coalition's energy policy for the next decade. Judging by his description of the "third continuation of the energy programme"' (the second continuation was in 1977), he had little money, little energy and few plans. Or at least he had few plans he would admit to, for fear of rocking the coalition.

For example, to prepare the third continuation, Lambsdorff had asked several German economic institutes to make forecasts of energy needs and production. Usually a government will give guideline projections for the total economy in such circumstances; but Lambsdorff could not or would not provide them. And while the institutes clearly recommended a quadrupling of nuclear power generation by 1995 (from 3.7 per cent of primary energy to 17 per cent), Lambsdorff would only commit himself to the remark that "nuclear energy must provide an increasing percentage of baseload electricity".

Several factors lie behind this imprecision - strong local opposition within the Social Democratic Party (SDP), one of the coalition partners, to the expansion of nuclear power; the possible retirement of Chancellor Schmidt through ill-health before the 1984 general elections, complicated by the lack of an obvious successor; and the forthcoming fight in the local government elections next year, when SDP must present as united a front as it can.

Were it not for these political complications, the government would no doubt like to commit itself firmly to cheap nuclear power, which - behind the scenes - it sees as essential for maintaining the competitiveness of German industry. But if nuclear power is to be cheap, it must be plentiful, goes the calculation. A new German 1,300-MW pressurized water nuclear power station would" cost nearly twice as much in Germany as in France, a German manufacturer claimed recently. According to the company, this is largely because the French companies were "tooled up" for long production runs, and environmental regulations and delays are less extreme in France. At best, nuclear power might contribute 25 per cent of German electricity by the mid-1980s, compared with France's 70 per cent by 1990 , the company estimated.

Nevetheless, it is not good politics in SDP at present to be seen to be a strong supporter of nuclear power, in spite of the fact that there seems recently to have been a change of mood among the German public. Germany's strong dependence on oil and gas keeps domestic energy prices high, and the nuclear industry's claims that 